\section{Wistar-Imamichi Rats Exhibit a Strong Resistance to Cadmium Toxicity}

\author{
Hideaki Shimada, ${ }^{a}$ Masaaki Nagano, ${ }^{b}$ \\ Akira Yasutake, ${ }^{b}$ and Yorishige Imamura ${ }^{c, *}$ \\ ${ }^{a}$ Faculty of Education, Kumamoto University, 2-40-1 \\ Kurokami, Kumamoto 860-8555, Japan, ${ }^{b}$ National Institute for \\ Minamata Disease, Minamata, Kumamoto 867-0008, Japan, \\ and ${ }^{c}$ Faculty of Pharmaceutical Sciences, Kumamoto Univer- \\ sity, 5-1 Oe-honmachi, Kumamoto 862-0973, Japan
}

(Received December 17, 2001; Accepted January 7, 2002)

The strain difference in the toxicity of cadmium (Cd) was examined in male rats. All rats of the WistarImamichi (Wistar-IM) strain survived for 7 days after treatment with $\mathrm{Cd}$ at a dose of $5.0 \mathrm{mg} / \mathrm{kg}$ body weight, whereas $80 \%$ of the Wistar strain and $100 \%$ of the Sprague-Dawley and Fischer strains died. These results indicate that the Wistar-IM strain has strong resistance to Cd. Furthermore, the metallothionein (MT) contents of the liver, kidney and testis of Wistar-IM rats were compared with those of Fischer rats. The strain difference in the toxicity of $\mathrm{Cd}$ in rats did not appear to result from a difference in MT content, although further study is necessary to elucidate the role of MT.

Key words — Wistar-Imamichi rat, cadmium toxicity, strain difference, metallothionein content

\section{INTRODUCTION}

Cadmium $(\mathrm{Cd})$ is an important environmental pollutant. Acute and chronic exposures to $\mathrm{Cd}$ can result in damage to a variety of tissues such as the liver, kidney and testis. ${ }^{1,2}$ The testis is the tissue most sensitive to $\mathrm{Cd}$, and acute exposure there causes a rapid hemorrhagic necrosis. ${ }^{3-5)}$ Interestingly, strain differences in Cd toxicity have been found in mice. Several mouse strains have been shown to be resistant to Cd-induced testicular necrosis. ${ }^{4,6)}$ Chellman et al. ${ }^{7)}$ and King et al. ${ }^{8,9)}$ observed a greater accumulation of $\mathrm{Cd}$ in the testis of sensitive than resistant mice. This is due to a strain difference in the speci-

\footnotetext{
*To whom correspondence should be addressed: Faculty of Pharmaceutical Sciences, Kumamoto University, 5-1 Oe-honmachi, Kumamoto 862-0973, Japan. Tel.: +81-96-371-4151; E-mail: yorishig@gpo.kumamoto-u.ac.jp
}

ficity of $\mathrm{Cd}$ transport mechanisms. Acute Cd toxicity is also manifested in the liver and kidney of mice, again with a difference among strains. ${ }^{10)}$

In rats, information on strain differences in $\mathrm{Cd}$ toxicity has been limited. $\mathrm{Cd}$ is a potent cell poison known to cause oxidative stress by increasing lipid peroxidation and by changing intracellular glutathione levels. ${ }^{11-13)}$ Rats exhibit a strain difference in hepatocellular oxidative stress mediated by a hepatotoxicant 1,2-dichlorobenzene. ${ }^{12)}$ A difference also exists in the hepatic antioxidant status between the Wistar-Kyoto and SD rat strains. ${ }^{13)}$ Furthermore, differential effects of progesterone pretreatment on Cd toxicity are observed between male Fischer and Wistar rats. ${ }^{14)}$ Thus, it is of interest to examine in detail the strain difference of $\mathrm{Cd}$ toxicity in rats. In the present study, we found that the Wistar-Imamichi (Wistar-IM) strain, derived from the Wistar strain, exhibits strong resistance to the lethal toxicity of $\mathrm{Cd}$ compared to other rat strains. Since the inducible Cd-binding protein metallothionein (MT) is often essential to $\mathrm{Cd}$ resistance, its concentrations in the liver, kidney and testis were also examined.

\section{MATERIALS AND METHODS}

Materials $\longrightarrow$ Cadmium chloride $\left(\mathrm{CdCl}_{2}\right)$ was purchased from Sigma (St. Louis, MO, U.S.A.). All other chemicals were of reagent grade.

Animals and Treatment — Male Fischer, Sprague-Dawley (SD) and Wistar rats at 8 weeks of age were purchased from Japan SLC (Shizuoka, Japan). Male Wistar-Imamichi (Wistar-IM) rats at 8 weeks of age were obtained from the Imamichi Institute for Animal Reproduction (Ibaraki, Japan). All animal experiments were undertaken in compliance with the guideline principles and procedures of Kumamoto University for the care and use of laboratory animals. $\mathrm{CdCl}_{2}$ dissolved in $0.5 \mathrm{ml}$ of saline solution was subcutaneously injected into the animals at a dose of $5.0 \mathrm{mg}$ of $\mathrm{Cd} / \mathrm{kg}$ of body weight. The animals were raised under controlled lighting, temperature and humidity for 7 days after Cd treatment. They had free access to a diet of standard laboratory chow and water. The survival rate $(\%)$ for 7 days was examined.

Measurement of MT — The amount of MT in the liver, kidney and testis of the animals before and $24 \mathrm{hr}$ after treatment with $\mathrm{Cd}$ at a dose of $2.0 \mathrm{mg} / \mathrm{kg}$ body weight was measured according to the method of Naganuma et al. $\left.{ }^{15}\right)$ 


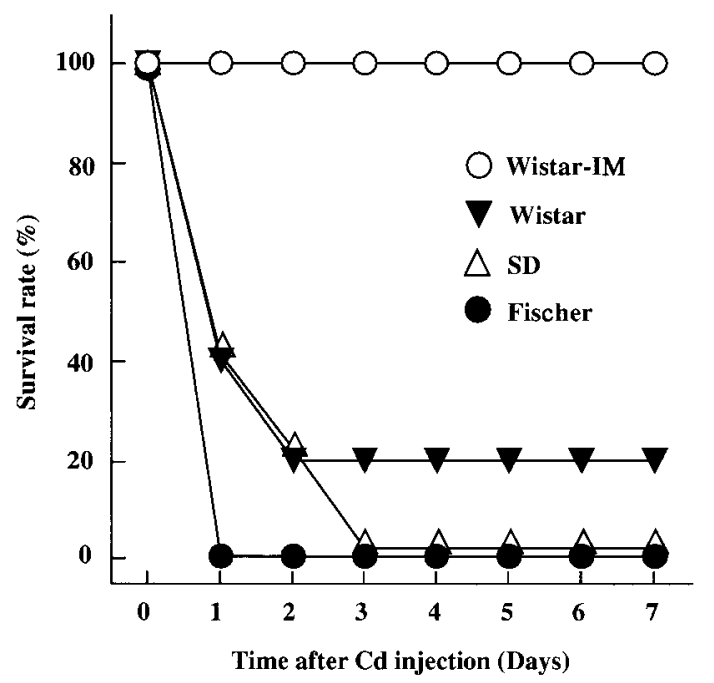

Fig. 1. Strain Difference in Lethal Toxicity of Cd in Male Rats The toxicity of $\mathrm{Cd}$ was expressed as the survival rate (\%). The experiment was performed using 5 or 6 rats of each strain.

Statistical Analysis — Data were analyzed using Student's $t$-test and $p<0.05$ was considered to be significant.

\section{RESULTS}

\section{Strain Difference in Toxicity of $\mathrm{Cd}$ in Male Rats}

Figure 1 shows the strain difference in the toxicity of $\mathrm{Cd}$ in male rats. All rats of the Wistar-IM strain survived for 7 days after treatment with $\mathrm{Cd}$ at a dose of $5.0 \mathrm{mg} / \mathrm{kg}$ body weight, whereas $80 \%$ of the Wistar strain and $100 \%$ of the SD and Fischer strains died.

\section{Hepatic, Renal and Testicular MT Concentrations in Male Wistar-IM and Fischer Rats}

The MT contents of the liver, kidney and testis of Wistar-IM rats were compared with those of Fischer rats. As shown in Fig. 2, the untreated rats showed a slight but significant strain difference in hepatic and testicular MT levels. However, the increased hepatic and renal MT levels $24 \mathrm{hr}$ after treatment with $\mathrm{Cd}$ at a dose of $2.0 \mathrm{mg} / \mathrm{kg}$ body weight were similar in Wistar-IM and Fischer rat strains, even though the testicular MT level in these two rat strains was not affected by the treatment with $\mathrm{Cd}$.

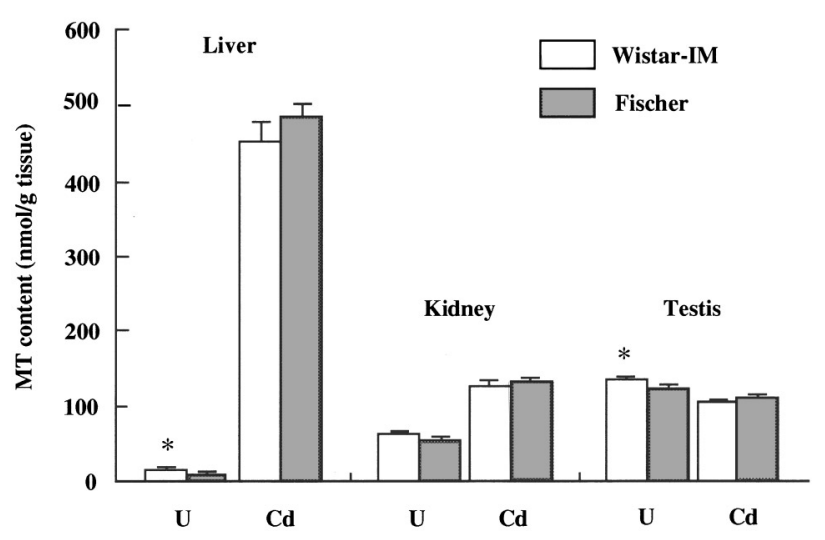

Fig. 2. Hepatic, Renal and Testicular MT Contents in Male Wistar-IM and Fischer Rats

Each bar represents the mean \pm S.D. of at least four rats. U; untreated rats, Cd; Cd-treated rats. * $p<0.05$, significantly different from MT content of the corresponding tissue in untreated Fischer rats.

\section{DISCUSSION}

The present study demonstrates that the WistarIM rat strain exhibits strong resistance to the toxicity of Cd compared to the Wistar, SD and Fischer strains. Even when the dose of $\mathrm{Cd}$ was increased from 5.0 to 6.5 or $8.0 \mathrm{mg} / \mathrm{kg}$ body weight, all rats of the Wistar-IM strain survived for 7 days after the treatment (data not shown). On the other hand, among males of the strains examined in this study, those of the Fischer strain, which is an inbred rat strain, had the highest sensitivity to $\mathrm{Cd}$. Since the Wistar-IM strain is also inbred, it is useful for genetic analysis. To establish whether the strong resistance to the toxicity of $\mathrm{Cd}$ is genetically regulated, we are currently analyzing the inheritance pattern of Cd resistance in rats by mating the Wistar-IM strain with the Fischer strain.

MT is known to be a metal-binding protein of low molecular weight that plays an important role in cellular defense against $\mathrm{Cd}^{16)}$ Thus, the MT contents of the liver, kidney and testis of Wistar-IM and Fischer rat strains were compared. In untreated rats, a slight but significant strain difference was observed in the hepatic and testicular levels. However, the strong resistance to $\mathrm{Cd}$ in the Wistar-IM rats cannot be explained on the basis of this slight difference. Furthermore, the hepatic and renal MT contents of Cd-treated Wistar-IM rats were similar to those, respectively, of Cd-treated Fischer rats. The difference of MT content is not likely to be causative of the observed strain difference of $\mathrm{Cd}$ resistance in rats, although further study is necessary to elucidate the role of MT. Recently, King et al. ${ }^{9)}$ reported differ- 
ences in $\mathrm{Cd}$ transport to the testis, epididymis and brain between Cd-sensitive and -resistant mouse strains. The strain difference of Cd toxicity in rats may also involve difference (s) in Cd transport to the liver, kidney and/or testis.

\section{REFERENCES}

1) Friberg, L., Elinder, C.-G., Kjellström, T. and Nordberg, G. F. (1986) Effects and responses. In Cadmium and Health: A Toxicological and Epidemiological Appraisal, vol. 1. Exposure, Dose and Metabolism (Friberg, L., Elinder, C.-G., Kjellström, T. and Nordberg, G. F., Eds.), CRC Press, Boca Raton FL, pp. 257-287.

2) Goering, P. L., Waalkes, M. P. and Klaassen, C. D. (1995) Toxicology of cadmium. In Toxicology of Metals, Biochemical Aspects: Handbook of Experimental Pharmacology, vol. 115. (Goyer, R. A. and Cherian, M. G., Eds.), Springer-Verlag, Berlin, Heidelberg, pp. 189-214.

3) Parizek, J. and Zahor, Z. (1956) Effect of cadmium salts on testicular tissue. Nature (London), 177, 1036-1037.

4) Gunn, S. A. and Gould, T. C. (1970) Cadmium and other mineral elements. In The Testes: Influencing Factors, vol. 3. (Johnson, A. D., Gomes, W. R. and VanDemark, N. L., Eds.), Academic Press, New York, pp. 377-481.

5) Shiraishi, N. and Waalkes, M. P. (1996) Acquired tolerance to cadmium-induced toxicity in the rodent testes. Toxic Subst. Mech., 15, 27-42.

6) Hata, A., Tsunoo, H., Nakajima, H., Shintaku, K. and Kimura, M. (1980) Acute cadmium intoxication in inbred mice. Chem. Biol. Interact., 32, 29-39.

7) Chellman, G. J., Shaikh, Z. A. and Baggs, R. B. (1984) Decreased uptake and altered subcellular disposition of testicular cadmium as possible mechanisms of resistance to cadmium-induced testicular necrosis in inbred mice. Toxicology, $\mathbf{3 0}$, 157-169.
8) King, L. M., Anderson, M. B., Sikka, S. C. and George, W. J. (1998) Murine strain differences and the effects of zinc on cadmium concentrations in tissues after acute cadmium exposure. Arch. Toxicol., 72, 650-655.

9) King, L. M., Banks, W. A. and George, W. J. (1999) Differences in cadmium transport to the testis, epididymis and brain in cadmium-sensitive and -resistant murine strains 129/J and A/J. J. Pharmacol. Exp. Ther., 289, 825-830.

10) Shaikh, Z. A., Jordan, S. A. and Tewari, P. C. (1993) Cadmium disposition and metallothionein induction in mice: strain-, sex-, age- and dose-dependent differences. Toxicology, 80, 51-70.

11) Stohs, S. J. and Bagchi, D. (1995) Oxidative mechanisms in the toxicity of metal ions. Free Radic. Biol. Med., 18, 321-336.

12) Younis, H. S., Hoglen, N. C., Kuester, R. K., Gunawardhana, L. and Sipes, I. G. (2000) 1,2Dichlorobenzene-mediated hepatocellular oxidative stress in Fischer-344 and Sprague-Dawley rats. Toxicol. Appl. Pharmacol., 163, 141-148.

13) Binda, D., Nicod, L., Viollon-Abadic, C., Rodriguez, S., Berthelot, A., Coassolo, P. and Richert, L. (2001) Strain differences (WKY, SPRD) in the hepatic antioxidant strains in rats and effect of hypertension (SHR, DOCA). Ex vivo and in vitro data. Mol. Cell. Biochem., 218, 139-146.

14) Shiraishi, N., Barter, R. A., Uno, H. and Waalkes, M. P. (1994) Effect of progesterone pretreatment on cadmium toxicity in male Fischer (F344/NCr) and Wistar (WF/NCr) rats. Environ. Health Rerspect., 102, Suppl. 3, 137-139.

15) Naganuma, A., Satoh, M. and Imura, N. (1987) Prevention of lethal and renal toxicity of cisdiamminedichloroplatinum (II) by induction of metallothionein synthesis without compromising its antitumor activity in mice. Cancer Res., 47, 983987.

16) Nordberg, M. and Nordberg, G. F. (2000) Toxicological aspects of metallothionein. Cell Mol. Biol., 46, 451-463. 